\title{
Preparation of porcelain tile granulates by more environmentally sustainable processes
}

\author{
C. GIL ${ }^{(1)}$; D. SILVESTREE ${ }^{(2)}$; J. PIQUER ${ }^{(3)}$; J. GARCíA-TEN( ${ }^{(4)} ;$ F. QUEREDA $^{(4)}$; M. J. VICENTE ${ }^{(4)}$ \\ Keros Cerámica, S.A.; ${ }^{(2)}$ Euroarce, S.A.; ${ }^{(3)}$ Neos Additives, S.L.; ${ }^{(4)}$ Instituto de Tecnología Cerámica (ITC). Asociación de Investigación de las \\ Industrias Cerámicas (AICE). Universitat Jaume I. Castellón. España.
}

Este trabajo ha sido presentado como comunicación oral, tras su evaluación por el Comité Científico, en el XII Foro Global del Recubrimiento Cerámico. QUALICER (13 y 14 febrero 2012. Castellón. España).

\begin{abstract}
This study examines the feasibility of manufacturing glazed porcelain tiles with a more environmentally friendly manufacturing process, by reducing water and thermal energy consumption. The process studied in this paper is dry milling in a pendulum mill, with subsequent granulation (in order to obtain a press powder with similar flowability to that of spraydried powders).

The different morphology of the new granulate with respect to the standard spray-dried granulate modifies the microstructure of the green compacts and thus, their behaviour and fired tile properties. In order to obtain porcelain tiles with the required properties (water absorption, mechanical strength,...) changes have been made in the raw materials mixture and in the processing variables.

Finally, porcelain tiles measuring 50x50 cm have been manufactured at industrial scale with the new granulate using a conventional firing cycle, obtaining quality levels identical to those provided by the spray-dried granulate. These results open the possibility of preparing porcelain tile body compositions through a manufacturing process alternative to the standard one, more environmentally friendly and with lower costs.
\end{abstract}

\section{Keywords: Porcelain tile, dry milling, granulation}

Preparación de granulados de gres porcelánico mediante procesos más sostenibles Medioambientalmente

En el presente trabajo se ha estudiado la viabilidad de fabricar gres porcelánico esmaltado utilizando un sistema de preparación de la composición del soporte más respetuoso con el medio ambiente, lo que implica una reducción importante de los consumos de agua y de energía térmica. El proceso que se estudia en el presente trabajo es el consistente en la molienda vía seca en molino pendular y en la posterior granulación (para obtener un polvo de prensas con fluidez similar a la de los polvos atomizados).

La distinta morfología de los nuevos gránulos obtenidos respecto al polvo atomizado actual, modifica la microestuctura en crudo de las piezas y, con ello, el comportamiento y propiedades finales de las baldosas obtenidas. Por ello, ha sido necesario modificar la mezcla de materias primas y ajustar algunas variables de operación para obtener baldosas de gres porcelánico con las propiedades requeridas (absorción de agua, resistencia mecánica, etc.).

Finalmente, se han fabricado industrialmente piezas de gres porcelánico $\left(50 \times 50 \mathrm{~cm}^{2}\right)$ con el nuevo granulado, mediante un ciclo de cocción convencional, obteniendo unos niveles de calidad idénticos a los que proporciona el polvo atomizado. Estos resultados abren la posibilidad de preparar las composiciones de soporte de gres porcelánico mediante un sistema alternativo al actual, más respetuoso con el medio ambiente y con un menor coste.

Palabras clave: Gres porcelánico, molienda en seco, granulación

\section{INTRODUCTION}

The most widely used process world-wide in porcelain tile manufacture, whether glazed or unglazed, is the so-called 'wet method' with single firing [1]. This manufacturing process entails significant consumption of energy and natural resources, including water. Average water consumption per square metre manufactured tile is about 20 litres, while energy consumption is about $32 \mathrm{kWh}$ per square metre manufactured tile [2].

About $60 \%$ of the water consumption occurs in milling the body composition. Although much of the water used is recycled [3], there are constraints for certain types of tile body because the solids contained in the water to be recycled could affect certain finished product characteristics, such as colour and fusibility, which limit recycling.

With regard to energy consumption, the greatest energy consumption (90\%) occurs in heating [2], so that energy improvements need to focus mainly on the reduction of this type of energy. The two stages that consume more than $90 \%$ of the thermal energy are spray drying of the body suspensions and tile firing. Although certain energy saving measures are being implemented in single-deck kilns [4], alternative technologies that would entail a significantly lower energy consumption to tile firing are currently not expected to emerge 
in the short-medium term. This study therefore examines an alternative technology to the present tile body preparation system with a view to reducing the related environmental loads of the tile manufacturing process. This involves significantly reducing the water consumption in this stage in order to suppress the suspension drying stage. The process studied in this paper is dry milling in a pendulum mill, with subsequent granulation (in order to obtain a press powder with similar flowability to that of spray-dried powders).

Laboratory studies may be found in the literature on porcelain tile fabrication by dry processing $[5,6]$, in which the importance of the particle size of the composition for obtaining the required properties is noted. However, no publications are available in which the powder granulation stage has been studied and pilot and industrial trials are included.

\section{EXPERIMENTAL}

This study was conducted with a granulate obtained by wet milling and spray drying (referenced AT) used in the manufacture of glazed porcelain tile, together with the plastic and non-plastic raw materials used. The chemical analysis of the AT granulate is detailed in Table I. These raw materials were used to prepare a granulate on a pilot scale (referenced GR) by milling the plastic raw materials in a pendulum mill (Poittemill P.M.-LB), followed by granulation (Eirich RV-02) of the milled clays together with the previously micronised nonplastic raw materials. The resulting granules, with a moisture content of about $13 \%$, were then dried to the required moisture content $(6 \%)$ for pressing.

The particle size distribution of the AT granulate (obtained by wet laser diffraction) and of the plastic and non-plastic raw materials (obtained by dry laser diffraction) are detailed in Figure 1. Although it is not entirely rigorous to compare the results obtained by dry and by wet laser diffraction [7], it may be observed that the particle size distribution of the composition obtained by both processes (pendulum mill and ball mill) lies in the same range of sizes.
The tests conducted on the different granulates were as follows:

- Granule size distribution (GSD).

- Hausner ratio.

- Compaction diagram (load-deformation curve).

- Dry mechanical strength

- Densification and vitrification diagram.

- Mechanical strength.

- Pyroplastic deformation.

The methods used to perform these tests may be found in the literature [8].

\section{RESULTS}

\subsection{Comparison between granulates AT and GR}

\subsubsection{GRANULE CHARACTERISTICS}

The granule size distribution (GSD) of samples AT and GR is depicted in Figure 2, while Figure 3 shows the appearance of the cross-sections of the two granulates. It may be observed that the GSD of sample GR exhibited a similar quantity of small granules $(<100 \mu \mathrm{m})$ to sample AT and a larger percentage of big granules $(500-1000 \mu \mathrm{m})$, indicating that the GSD had shifted towards larger-sized granules. With regard to granule appearance, sample GR granules did not display the characteristic centre void of spray-dried granules, but exhibited a greater compactness and lower sphericity with respect to granulate AT.

With a view to establishing whether these differences influenced the rheological behaviour of the granulate, the Hausner ratio of the two samples was determined. The results are presented in Table II. The table shows that the filling density of granulate GR $\left(\rho_{0}\right)$ was much higher because GR granule density was notably higher than that of the AT granules. After the bed had been consolidated by vibration

Table I. Chemical composition of SAmple AT.

\begin{tabular}{|c|c|c|c|c|c|c|c|c|c|}
\hline Oxide & $\mathrm{SiO}_{2}$ & $\mathrm{Al}_{2} \mathrm{O}_{3}$ & $\mathrm{Fe}_{2} \mathrm{O}_{3}$ & $\mathrm{CaO}$ & $\mathrm{MgO}$ & $\mathrm{Na}_{2} \mathrm{O}$ & $\mathrm{K}_{2} \mathrm{O}$ & $\mathrm{TiO}_{2}$ & L.O.I. \\
\hline Content & 68.7 & 19.2 & 0.64 & 0.58 & 0.58 & 4.27 & 1.67 & 0.69 & 3.47 \\
\hline
\end{tabular}

TABLE II. HAUSNER RATIO OF THE TEST SAMPLES.

\begin{tabular}{|c|c|c|c|}
\hline Samples & $\rho_{0}\left(\mathbf{k g} / \mathbf{m}^{3}\right)$ & $\rho_{\mathrm{f}}\left(\mathbf{k g} / \mathbf{m}^{3}\right)$ & Hausner ratio \\
\hline AT & 976 & 1210 & 1,24 \\
\hline GR & 1119 & 1419 & 1,27 \\
\hline
\end{tabular}

TABLE III. CHARACTERISTICS OBTAINED FROM THE LOAD-DEFORMATION CURVES.

\begin{tabular}{|c|c|c|}
\hline Characteristic & AT & GR \\
\hline Axial expansion (\%) & 3.09 & 2.59 \\
\hline Diametral expansion (\%) & 0.79 & 0.58 \\
\hline Yield pressure $\left(\mathbf{k g} / \mathbf{c m}^{2}\right)$ & 2.9 & 3.2 \\
\hline
\end{tabular}


$\left(\rho_{\mathrm{f}}\right)$, the same trend was observed, so that the Hausner ratios $\left(\rho_{\mathrm{f}} / \rho_{0}\right)$ of both granulates were similar. These results indicate that the larger size and greater density of the GR granules would offset the decreased flowability that they might be expected to display in view of their lower sphericity.

\subsubsection{GRANULATE BEHAVIOUR IN THE PRE-FIRING STAGES}

The results obtained in constructing the compaction diagrams of the granulates are presented in Figure 4 and Table III.

The following may be observed:

- Granulate GR displayed a higher bulk density $(\rho)$ at low pressure $(\mathrm{P})$ than $\mathrm{AT}$, which was consistent with the density values of the consolidated bed noted above.

- Inside the die, the evolution of bed bulk density (curve slope) of granulate GR ran parallel to that of AT. In granulate GR, however, a light delay in the pressure at which the change in slope occurred in the $\rho-P$ curves (known as the yield pressure) was observed, indicating that the GR granules had a greater deformation resistance.

- The bulk density reached for the GR granulate at maximum pressure was much higher than that for the AT granulate. The main reason for the difference was the greater density of the GR granules.

- The after-pressing axial expansion, as well as the diametral expansion, of the pieces was lower when the GR granulate was used.

In order to characterise the unfired pieces, the pressing conditions used in industry (pressing pressure: $380 \mathrm{~kg} / \mathrm{cm}^{2}$; dry bulk density: $1.95 \mathrm{~g} / \mathrm{cm}^{3}$ ) for granulate AT were taken as a reference. Granulate GR was processed under two pressing conditions: a) a pressing pressure that provided a dry bulk density of $1.95 \mathrm{~g} / \mathrm{cm}^{3}$ and b) a pressing pressure of $380 \mathrm{~kg} /$ $\mathrm{cm}^{2}$. The results obtained are presented in Table IV. The following may be observed:

- $\quad$ The pressure required for the GR granulate to provide a similar dry bulk density to that of the spray-dried powder was just $110 \mathrm{~kg} / \mathrm{cm}^{2}$. It is quite likely that, at that pressure, the granules had not been completely deformed, which explains the low mechanical strength and high permeability of the test pieces.

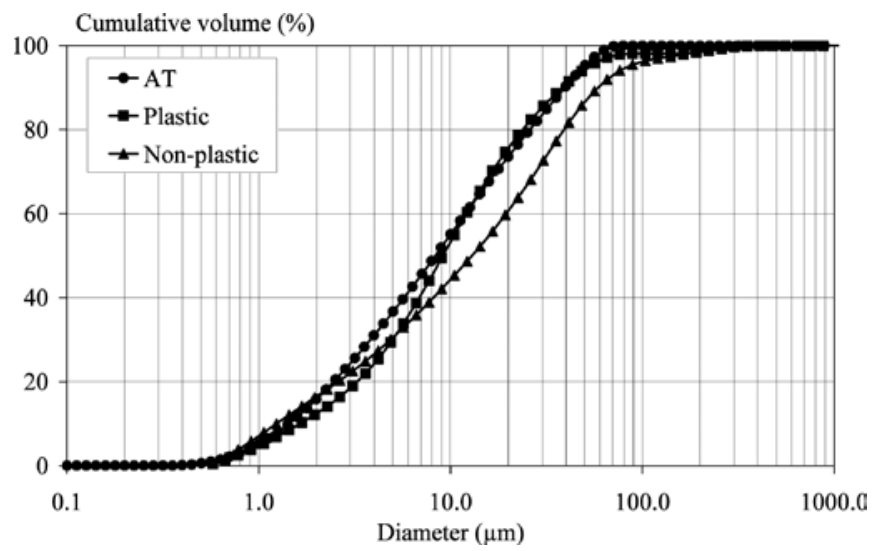

Figure 1. Particle size distribution.

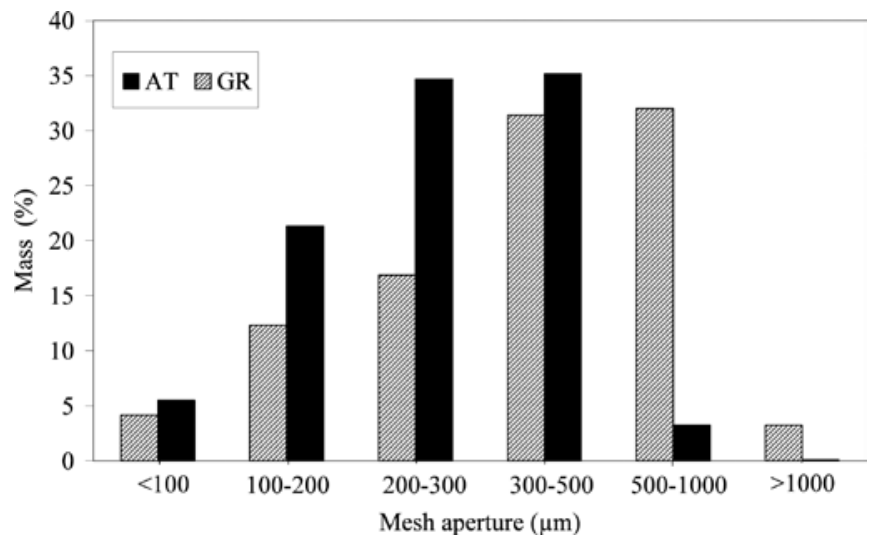

Figure 2. Granule size distribution
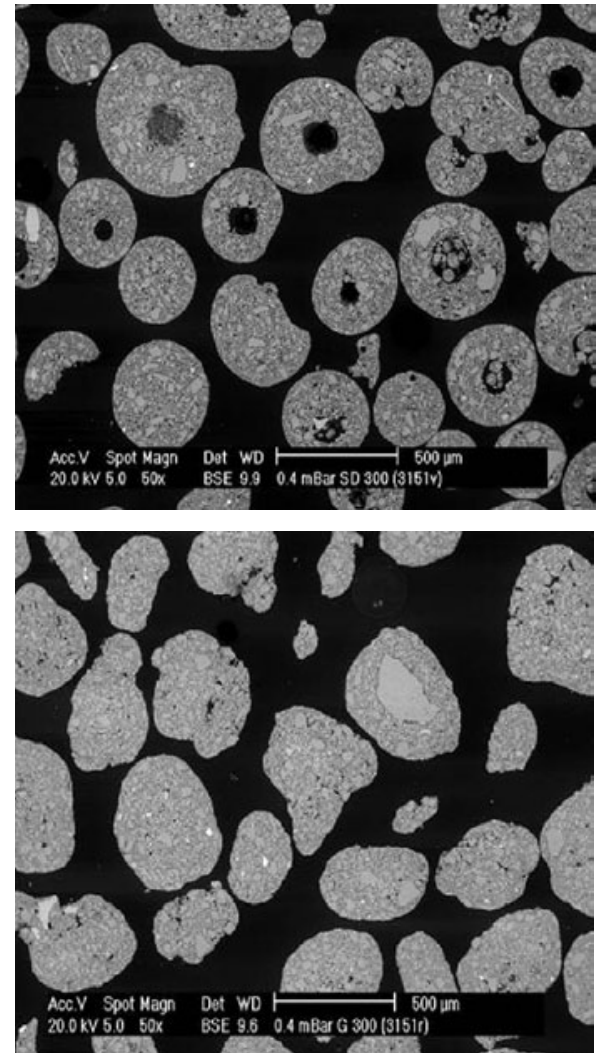

Figure 3. Micrograph of the two types of granulates; top: AT, bottom: GR

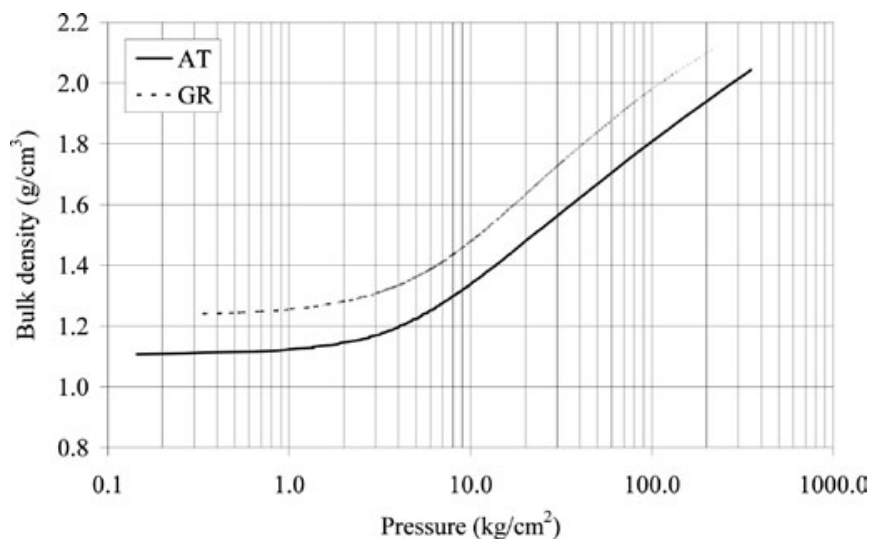

Figure 4. Compaction diagram of the granulates 
- When the pressure was not changed $\left(380 \mathrm{~kg} / \mathrm{cm}^{2}\right)$, the pieces formed with the GR granulate displayed a very high dry bulk density $\left(2.12 \mathrm{~g} / \mathrm{cm}^{3}\right)$, in addition to a high mechanical strength, but a low permeability. The use of an intermediate pressure may be expected to provide similar values of both characteristics to those of the AT granulate.

The greater dry mechanical strength and lower coefficient of permeability of the test pieces formed from the GR granulate under conditions b) may be explained by the greater dry bulk density of the test pieces. In order to determine why the mechanical strength decreased and the permeability increased in the test pieces obtained under conditions a), freshly fractured sections were examined by optical microscopy (Figure 5). It was observed that while the AT pieces displayed a quite smooth and homogeneous texture, the GR pieces exhibited a very rough and irregular fracture cross-section, in which numerous granules had not completely deformed. This led to an unfired microstructure with numerous large microstructural defects (intergrain porosity), which could initiate cracks and progress with relative ease, giving rise to low mechanical strength. Another factor that contributed favourably to the obtainment of good mechanical strength in the AT granulate was the migration of the deflocculant (sodium silicate) to the granule surface during the spray-drying process, which acted as a binder [9].

\subsubsection{FIRING BEHAVIOUR AND PROPERTIES OF THE FIRED PIECE}

The vitrification diagrams of the test pieces are shown in Figure 6, while their properties at maximum densification
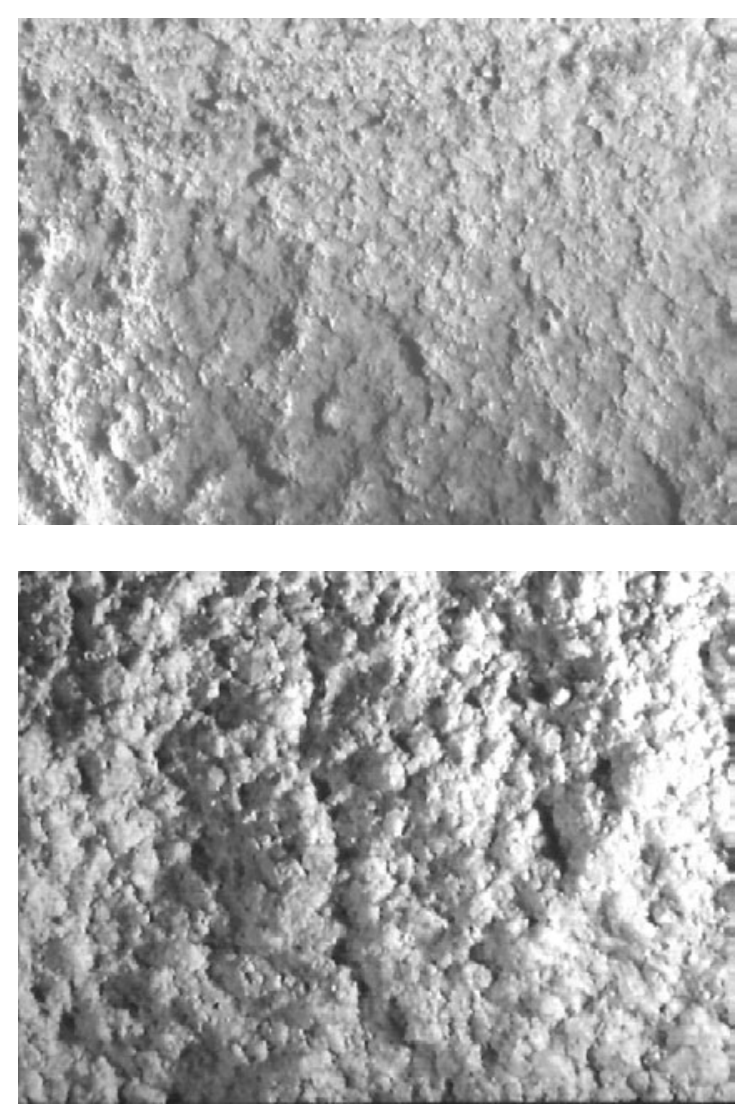

Figure 5. Appearance of the fracture cross-section; top: AT, bottom: GR temperature (Tmax) are presented in Table V. The following may be observed:

- The pressing pressure had a notable influence on the behaviour during firing of the GR granulates. Thus, when the pieces were formed under conditions a), the maximum densification reached was only $2.29 \mathrm{~g} / \mathrm{cm}^{3}$ and the pieces began to expand at temperatures far below those at which the required water absorption was obtained $(0.5 \%)$. These conditions are inappropriate for processing the pieces, since the obtainment of low water absorption would entail operating in the zone of excessive bloating, which would lead to pyroplastic deformation in the pieces.

- With the GR granulate formed under conditions b), a high degree of densification $\left(2.40 \mathrm{~g} / \mathrm{cm}^{3}\right)$ and a water absorption of $0.8 \%$ were reached. If it was desired to reduce the water absorption below that value, the pieces would also need to be fired at a temperature slightly above Tmax, though in this case the bloating process was not very pronounced.

- Comparison of the results of the GR granulate formed under conditions $b$ ) with those corresponding to the AT granulate shows that there were significant differences between both. Thus, at low temperatures (1140-1160 $\left.{ }^{\circ} \mathrm{C}\right)$, the pieces made from the GR granulate displayed a higher bulk density and lower water absorption. However, the greater difficulty in vitrifying the pieces obtained from the GR granulate, as may be inferred from the smaller slope of water absorption (WA) with temperature (T), would make it difficult to obtain a low water absorption at lower temperatures than the bloating temperature.

TABLE IV. CHARACTERISTICS OF THE DRY TEST PIECES.

\begin{tabular}{|c|c|c|c|}
\hline Characteristic & \multirow{2}{*}{ AT } & \multicolumn{2}{|c|}{ GR } \\
\hline Moisture content $(\%)$ & 5.5 & 6.0 & 6.0 \\
\hline Pressure $\mathbf{( k g / \mathbf { c m } ^ { 2 } )}$ & 380 & 110 & 380 \\
\hline Dry bulk density $\left.\mathbf{g} / \mathrm{cm}^{3}\right)$ & 1.947 & 1.948 & 2.122 \\
\hline Dry mechanical strength $\left(\mathbf{k g} / \mathrm{cm}^{2}\right)$ & 35 & 19 & 47 \\
\hline Coefficient of permeability $\left(\mathbf{m}^{\mathbf{2}} \mathbf{1 0} \mathbf{1 0}\right)$ & 1.3 & 20 & 0.7 \\
\hline
\end{tabular}

TAble V. Properties of the test Pieces at TMaX.

\begin{tabular}{|c|c|c|}
\hline Characteristics & AT & GR - b) \\
\hline Tmax $\left({ }^{\circ} \mathbf{C}\right)$ & 1195 & 1179 \\
\hline Bulk density $\left(\mathbf{g} / \mathbf{c m}^{\mathbf{3}}\right)$ & 2.380 & 2.409 \\
\hline Linear shrinkage (\%) & 7.3 & 5.3 \\
\hline Water absorption (\%) & $<0.5$ & 0.8 \\
\hline Loss on ignition (\%) & 3.40 & 3.57 \\
\hline $\mathbf{L}^{*}$ & 72.2 & 73.5 \\
\hline $\mathbf{a}^{*}$ & 2.6 & 2.6 \\
\hline $\mathbf{b}^{*}$ & 13.2 & 13.0 \\
\hline Fired mechanical strength $\left.\mathbf{( k g}^{*} \mathbf{c m}^{2}\right)$ & $550 \pm 10$ & $500 \pm 10$ \\
\hline Pyroplasticity index $\left.\mathbf{x} \mathbf{1 0} \mathbf{( c m}^{\mathbf{*}}\right)$ & 2.8 & 2.2 \\
\hline
\end{tabular}


TABLE VI. UNFIRED PROPERTIES OF THE PREPARED GRANULATES.

\begin{tabular}{|c|c|c|c|c|}
\hline Composition & AT & GR & ATm & ATg \\
\hline Moisture content (\%) & 5.5 & 6.0 & 6.0 & 6.0 \\
\hline Pressure $\left(\mathrm{kg} / \mathrm{cm}^{2}\right)$ & 380 & 380 & 380 & 380 \\
\hline Dry bulk density $\left(\mathrm{g} / \mathrm{cm}^{3}\right)$ & 1.947 & 2.112 & 1.941 & 2.070 \\
\hline
\end{tabular}

With regard to the properties of the pieces fired at Tmax, these were only measured for the pieces made from the GR granulate formed under conditions $b$ ). These pieces displayed the following differences with respect to those of the pieces obtained with the AT granulate:

- Lower firing shrinkage and greater dimensional stability.

- Similar degree of whiteness.

- Slightly lower fired mechanical strength.

- Lower pyroplastic deformation owing to the lower value of Tmax.

\subsubsection{INFLUENCE OF THE GRANULATION PROCESS}

The differences observed in the vitrification process (WA-T curves) between the AT and GR granulates could be due to the dispersion of the clay in water and to the use of deflocculants in the case of granulate AT, as well as the different granulation method used. For that reason, in this section, two new samples were prepared from the AT granulate. In the first, the AT granulate was milled in a pendulum mill (ATm) whereas in the second, the spray-dried powder milled in the pendulum mill was granulated (ATg). Milling and granulation were performed under the same conditions as those used to prepare the GR granulate.

The new granulate (ATg) displayed a very similar granule size distribution to that of the GR granulate, which allowed the conclusion to be drawn that this characteristic did not depend on the milling process (dry or wet milling) used. The results obtained with regard to pressing behaviour are detailed in Table VI. The milled AT granulate (ATm) was observed to display a similar pressing behaviour to that of the AT granulate, while on granulating the milled spray-dried powder again (ATg), its pressing behaviour was quite similar to that of the GR granulate. These results indicate that, when the particle size distribution remained constant, pressing behaviour depended mainly on how the granules were obtained (spray drying/granulation) and, hence, on granule characteristics. These results are consistent with those found for red-body stoneware tile compositions [8].

The vitrification diagrams obtained are compared in Figure 7, while the properties at Tmax are compared in Table VII. They show that the firing behaviour and properties at Tmax of the milled spray-dried powder (ATm) were similar to those of the AT granulate, and that the behaviour and properties at Tmax of the granulated spray-dried powder (ATg) were very similar to those of granulate GR. It was therefore concluded that the different evolution of water absorption with temperature of the AT and GR granulates was due to the different unfired microstructure resulting from the two granulation methods used.

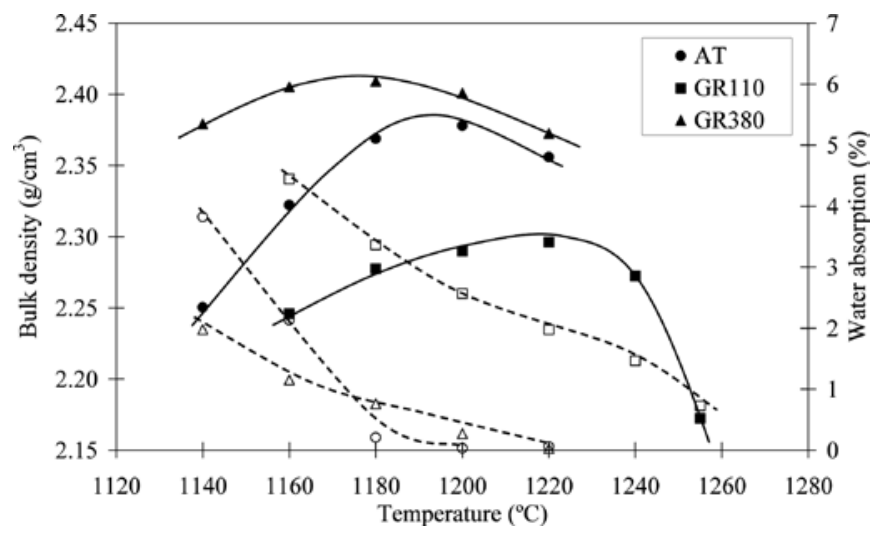

Figure 6. Evolution of bulk density and water absorption with temperature.

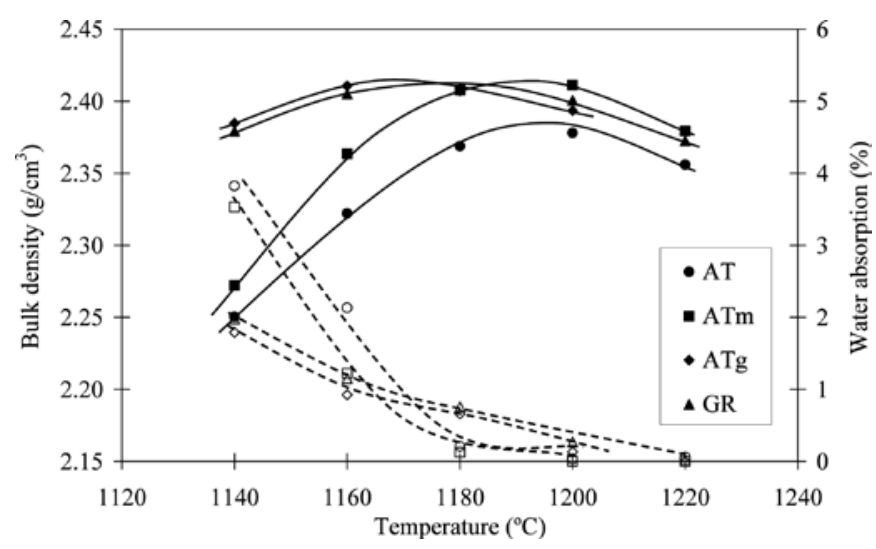

Figure 7. Evolution of bulk density and water absorption with temperature.

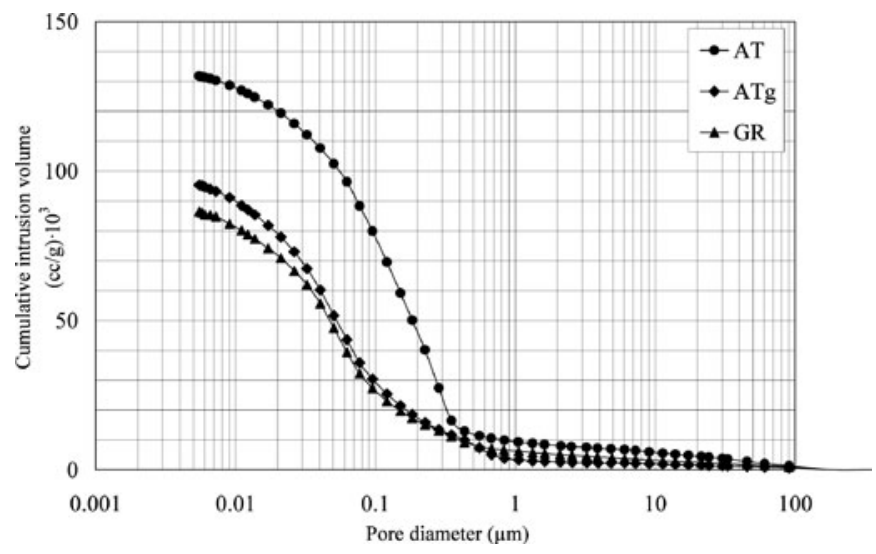

Figure 8. Pore size distribution of the test samples 
In order to establish whether the different firing behaviour of the AT and GR granulates was due to the existence in the latter of large-sized pores that could not be eliminated or closed during firing, the pore size distribution of test pieces pressed from the different granulates was determined (Figure 8). The figure shows that the pore size distribution of the granulated spray-dried powder (ATg) was very similar to that obtained with the GR granulate. With relation to the pore size distribution obtained in the test piece pressed with the AT granulate, the only difference to be observed was that the total pore volume was greater, while the volume of large-sized pores was similar.

These results were in contrast with the differences observed in the firing behaviour of the GR and AT granulates. As a result, it was decided to analyse the microstructure of the fired test pieces in the temperature range in which the greatest differences were observed between the two granulates, i.e. between 1160 and $1180{ }^{\circ} \mathrm{C}$. Test pieces fired at the two temperatures were therefore polished and observed using the bright-field signal of an optical microscope (Figure 9). These images clearly show that the pieces corresponding to the GR granulate contained larger-sized pores with respect to those of the AT granulate, which corresponded mainly to initial intergrain voids, which it was not possible to detect under the conditions used in performing the pore-size tests. The granule boundaries that defined the intergrain pores can even be detected in the images. In addition, these pores were connected and reached the test piece surface (Figure 10), giving rise to the apparent porosity (water absorption) in the test pieces fired at Tmax.

These results indicate that GR granulate pressing behaviour and the properties that it contributed to the different pieces differed noticeably with respect to those observed when the AT granulate was used. The main difference stemmed from the lower deformability of the GR granules, which would require the use of very high pressing pressures $\left(>400 \mathrm{~kg} / \mathrm{cm}^{2}\right)$ in order to achieve complete deformation during pressing. This would involve the obtainment of unfired pieces with high density, which would provide them with very good mechanical properties and very low permeability. Under the customary pressing conditions used in industrial practice $(\sim 350 \mathrm{~kg} /$ $\mathrm{cm}^{2}$ ), the GR granulate, owing to its low deformability during pressing, yielded unfired pieces with large intergrain pores, which slowed the vitrification process and made it difficult to obtain very low water absorption at temperatures below the bloating temperature.

The foregoing indicates that the manufacture of glazed porcelain tile by a dry milling and granulation process would require obtaining an unfired microstructure that was as homogeneous as possible, without large-sized pores, since such pores adversely affect the mechanical properties of the unfired and the fired pieces, and delay the vitrification process.

\subsection{Acceleration of the vitrification process}

In order to increase the water absorption-temperature curve slope in the GR granulate, tests were performed by raising the pressing moisture content to $8 \%$ (in order to increase granule deformability), decreasing granule size below 500 and $300 \mu \mathrm{m}$ (with a view to reducing intergrain void size in the unfired pieces), and modifying the plastic fraction/ non-plastic fraction ratio. None of these modifications led to significant changes in the vitrification rate of the pieces. It was decided, therefore, to incorporate vigorous fluxes that would mainly act in the intergrain voids stemming from the granule boundaries. A soluble flux (GRs granulate) was tested, which was incorporated into the granulation water, so that, after the granules had dried, this would migrate to the granule surface just as occurs during the spray-drying process, and an insoluble flux (GRi granulate) with which the GR granules were coated by means of an identical procedure to that used in dry-colouring technology [10].The results obtained are shown in Figure 11. It may be observed that the soluble flux (GRs) increased the slope of the WA-T curve with respect to that of the GR granulate: however, it reduced Tmax significantly,

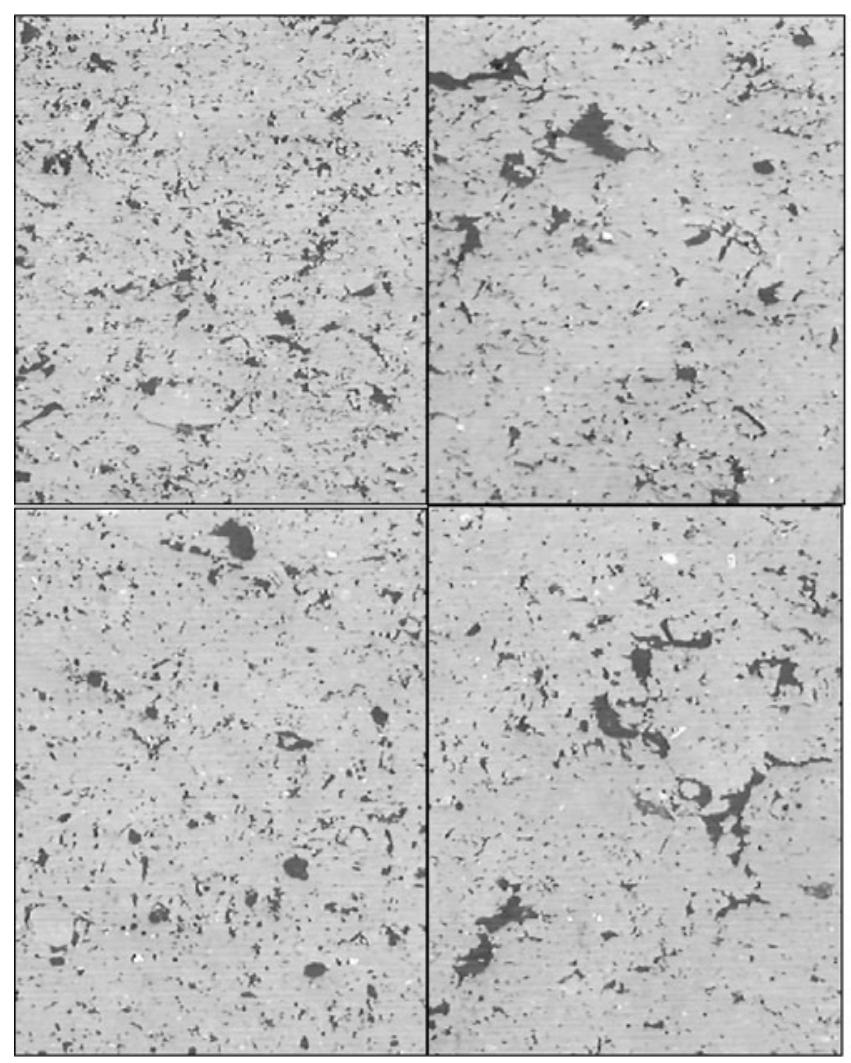

Figure 9. Comparison of the cross-section of samples AT (left) and GR (right) at $1160{ }^{\circ} \mathrm{C}$ (top) and $1180{ }^{\circ} \mathrm{C}$ (bottom).

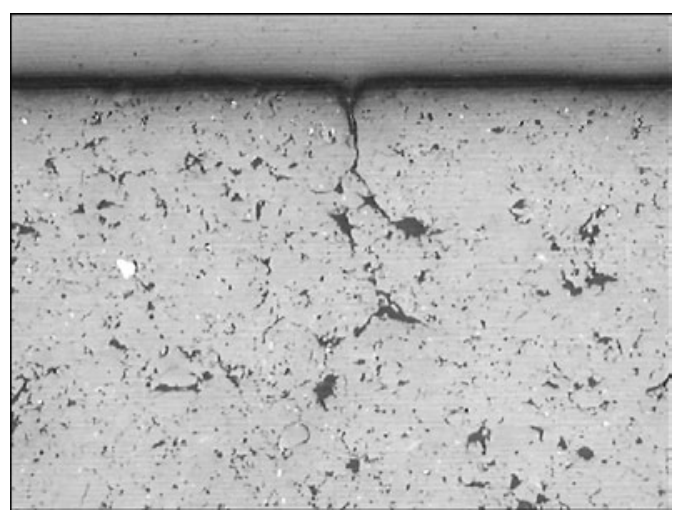

Figure 10. Cross-section of the GR sample at $1160^{\circ} \mathrm{C}$. 
TABle VII. Properties OF THE TeSt PIECES AT TMAX.

\begin{tabular}{|c|c|c|c|c|}
\hline Composition & AT & GR & ATm & 1191 \\
\hline Tmax $\left({ }^{\circ} \mathbf{C}\right)$ & 1195 & 1179 & 2.414 & 1168 \\
\hline Bulk density $\left(\mathrm{g} / \mathrm{cm}^{3}\right)$ & 2.380 & 2.409 & 7.5 & 2.412 \\
\hline Linear shrinkage (\%) & 7.3 & 5.3 & $<0.1$ & 0.1 \\
\hline Water absorption (\%) & $<0.1$ & 0.8 & $<$ \\
\hline
\end{tabular}

TABLE VIII. DATA CORRESPONDING TO THE INDUSTRIAL TRIALS.

\begin{tabular}{|c|c|c|c|}
\hline Composition & AT & GR & GRi \\
\hline Moisture content (\%) & 6.0 & 6.0 & 6.1 \\
\hline Pressure $\left(\mathrm{kg} / \mathrm{cm}^{2}\right)$ & 275 & 275 & 275 \\
\hline Average dry bulk density $\left(\mathrm{g} / \mathrm{cm}^{3}\right)$ & 1.96 & 2.09 & 2.07 \\
\hline Dry mechanical strength $\left(\mathrm{kg} / \mathrm{cm}^{2}\right)$ & 22 & 23 & 22 \\
\hline Temperature $\left({ }^{\circ} \mathrm{C}\right)$ & 1195 & 1195 & 1195 \\
\hline Cycle (min) & 60 & 60 & 60 \\
\hline Fired bulk density $\left(\mathrm{g} / \mathrm{cm}^{3}\right)$ & 2.37 & 2.40 & 2.37 \\
\hline Linear shrinkage (\%) & 7.0 & 5.7 & 5.7 \\
\hline Water absorption $(\%)$ & $<0.1$ & 0.4 & $<0.1$ \\
\hline Mechanical strength $\left(\mathrm{kg} / \mathrm{cm}^{2}\right)$ & $460 \pm 12$ & $510 \pm 15$ & $480 \pm 13$ \\
\hline
\end{tabular}

which prevented a low water absorption from being reached before bloating. In contrast, the insoluble flux (GRi) modified the WA-T curve to a greater extent, a slope being reached that was similar to that of the AT granulate without noticeably modifying the value of Tmax. This allowed very low water absorption $(0.1 \%)$ to be achieved before bloating occurred.

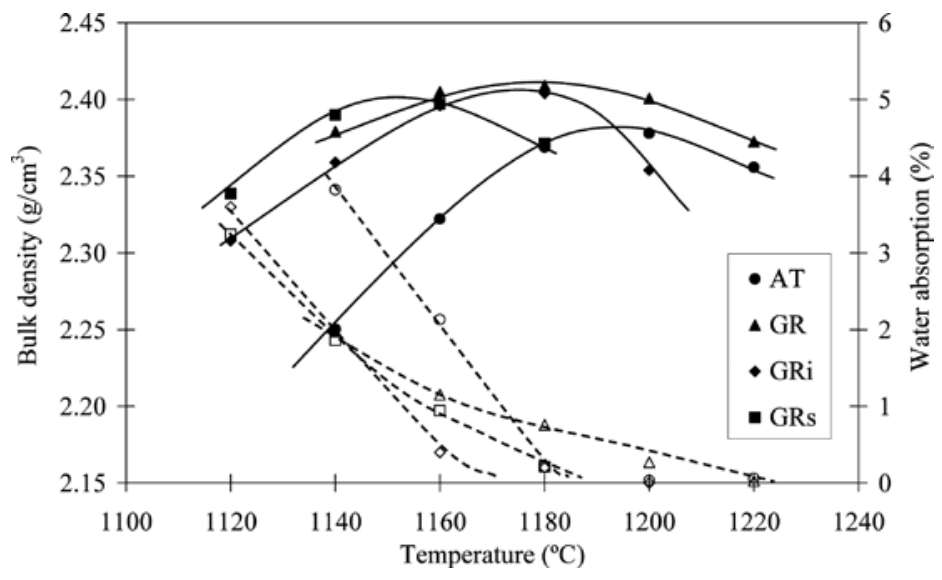

Figure 11. Evolution of bulk density and water absorption with temperature.

\subsection{Industrial trials}

To conclude the study, industrial trials were conducted for which the GR and GRi granulates were prepared in a semi-industrial facility. These granulates were used to press pieces measuring 50x50 cm, which were glazed and fired in an industrial facility that produced glazed porcelain tile. The conditions under which the pieces were made were identical to production conditions.

During the performance of the trials, no manufacturing problems such as cracks, fracture, or surface defects in the fired glaze were detected. With regard to dimensional parameters, beside the larger size of the pieces, the fabricated lot exhibited high uniformity, without any calibres, departures from rectangularity, or lack of planarity, as was to be expected given the uniformity of the unfired bulk density values in the same piece and those of different pieces. Some of the characteristics of the pieces are given in Table VIII.

\section{CONCLUSIONS}

The following conclusions may be drawn from the present study:

- The dry milling process with a dynamic sorter provides clays with controlled particle sizes similar to those obtained by wet milling in ball mills. 
- The proposed granulation system produces solid granules with a higher density than that of the granulate obtained by spray drying, while they have a somewhat larger particle size. The flowability of the new granulate is identical to that of the spray-dried granulate.

- In the industrial trials conducted with pieces measuring $50 \times 50 \mathrm{~cm}$, it was observed that the new granulates provided greater compactness, a very uniform bulk density distribution in the pressed pieces, and similar dry mechanical strength values with respect to those of the spray-dried granulate. No manufacturing problems were detected during the pressing, drying, and glazing stages.

- The lower deformability of the GR granules during pressing led to intergrain porosity in the unfired pieces, which reduced the vitrification rate of the pieces and, consequently, made it difficult to obtain tiles with zero water absorption before bloating of the pieces occurred.

- By using certain additives, it was possible to increase the vitrification rate to levels resembling those of the spray-dried granulate. The (GRi) composition yielded glazed porcelain tiles with zero water absorption under the customary firing conditions. The pieces obtained displayed an identical level of quality to those made in production.

- The use of this technology in polished porcelain tile manufacture is not considered advisable at the moment owing to the presence of residual intergrain porosity inside the pieces, which could reduce the product's gloss and stain resistance.

- Although the relevant data have not been included in the text for lack of space, the new preparation process of the proposed composition is able to recycle the arising wastes in the ceramic manufacturing process and, in addition, is more energy and environmentally efficient. The process reduces overall energy consumption by $55 \%$, water consumption by $75 \%$, and $\mathrm{CO}_{2}$ emissions by $65 \%$.

\section{ACKNOWLEDGEMENTS}

The authors thank the Ministry of Science and Innovation for the financing received to conduct the project (IAP560620-2008-35) and thank the company Eirich-Molaris for its collaboration in the preparation of the granulates for the industrial trials.

\section{REFERENCES}

(1) SÁNCHEZ, E.; GARCÍA-TEN, J.; SANZ, V.; MORENO, A. Porcelain tile: almost 30 years of steady scientific-technological evolution. Ceram. Int., 36, 831-845, 2010.

(2) MONFORT, E.; MEZQUITA, A.; GRANEL, R., et al. Análisis de consumos energéticos y emisiones de dióxido de carbono en la fabricación de baldosas cerámicas. Bol. Soc. Esp. Ceram. Vidr., 49(4), 303-310, 2010.

(3) ENRIQUE, J.E.; MONFORT, E.; BUSANI, G.; MALLOL, G. Reciclado de aguas residuales en la fabricación de baldosas cerámicas. Bol. Soc. Esp. Ceram. Vidr., 39(1), 149-154, 2000.

(4) MEZQUITA, A.; MONFORT, E.; VAQUER, E., et al. Optimización energética en la fabricación de baldosas cerámicas mediante el uso de aceite térmico. Qualicer 2012: XI World Congress on Ceramic Tile Quality. Castellón: Cámara Oficial de Comercio, Industria y Navegación.

(5) MELCHIADES, F.G.; DAROS, M.T.; ZANELATTO, F.C.; BOSCHI, A.O. Porcelain tiles produced by the dry route. Interceram, 59 (1), 13-17, 2010.

(6) SAMPAIO, V.G.; PINHEIRO, B.C.A.; HOLANDA, J.N.F. Dry granulation of a ceramic paste for porcelain stoneware tile. Cerâmica, 53, 295-299, 2007.

(7) ORTS, M.J.; CAMPOS, B.; PICÓ, M.; GOZALBO, A. Métodos de análisis granulométrico. Aplicación al control de la granulometría de las materias primas. In: Proceedings of II World Congress on Ceramic Tile Quality. Castellón. Cámara Oficial de Comercio, Industria y Navegación, 293-312, 1992.

(8) AMORÓS ALBARO, J.L. Pastas cerámicas para pavimentos de monococción. Influencia de las variables del proceso sobre las propiedades de la pieza en crudo y sobre su comportamiento durante el prensado y la cocción. (Ph.D. thesis) University of Valencia, Department of Chemical Engineering, 1987.

(9) REED, J.S. Principles of ceramics processing. 2nd ed. New York: John Wiley and Sons, 1995. Chap. 20. Granulation, pp 378-393.

(10) GARCÍA-TEN, J.; MORENO, A.; QUEREDA, F., et al. El proceso de coloreado en seco del gres porcelánico. Variables implicadas e influencia sobre las propiedades de las piezas. In: Qualicer 2008: X World Congress on Ceramic Tile Quality. Castellón: Cámara oficial de comercio, industria y navegación, 2008. pp. P.BC299-P.BC317. 